\title{
An Assessment of Competency-Based Simulations on E-Learners' Management Skills Enhancements
}

\author{
Yair Levy \\ Nova Southeastern University, \\ College of Engineering and \\ Computing, \\ Ft. Lauderdale, Florida, USA \\ levyy@nova.edu
}

\author{
Michelle M. Ramim \\ Hodges University, \\ Fisher School of Technology \\ Naples, Florida, USA
}

\begin{abstract}
There is a growing interest in the assessment of tangible skills and competence. Specifically, there is an increase in the offerings of competency-based assessments, and some academic institutions are offering college credits for individuals who can demonstrate adequate level of competency on such assessments. An increased interest has been placed on competency-based computer simulations that can assist learners to gain tangible skills. While computer simulations and competency-based projects, in general and particularly in management, have demonstrated great value, there are still limited empirical results on their benefits to e-learners. Thus, we have developed a quasi-experimental research, using a survey instrument on pre- and post-tests, to collect the set of 12 management skills from e-learners attending courses that included both competency-based computer simulations and those that didn't. Our data included a total of 253 participants. Results show that all 12 management skills measures demonstrated very high reliability. Our results also indicate that all 12 skills of the competency-based computer simulations had higher increase than those that didn't. Analyses on the mean increases indicated an overall statistically significant difference for six of the 12 management skills enhancements between the experimental and control groups. Our findings demonstrate that overall computer simulations and competency-based projects do provide added value in the context of e-learning when it comes to management skills.
\end{abstract}

Keywords: competency-based projects in e-learning, simulations in e-learning, managerial skills enhancements, management skills in elearning, self-reported skills.

Material published as part of this publication, either on-line or in print, is copyrighted by the Informing Science Institute. Permission to make digital or paper copy of part or all of these works for personal or classroom use is granted without fee provided that the copies are not made or distributed for profit or commercial advantage AND that copies 1) bear this notice in full and 2) give the full citation on the first page. It is permissible to abstract these works so long as credit is given. To copy in all other cases or to republish or to post on a server or to redistribute to lists requires specific permission and payment of a fee. Contact Publisher@InformingScience.org to request redistribution permission.

\section{Introduction}

Recently, Competency-Based Learning (CBL) has been debated in higher education and professional development training, including in for-credit professional re-certification courses. According to the United States (U.S.) Department of Education, CBL enables learn-

Editor: Janice Whatley

Submitted May 17, 2015; Revised October 5, 2015; Accepted: October 5, 2015 An earlier, shorter version of this paper was presented at the Chais conference 2015, in Raanana, Israel, and included in Y. Eshet-Alkalai, I. Blau, A. Caspi, N. Geri, Y. Kalman, \& V. Silber-Varod (Eds.), Proceedings of the 10th Chais Conference for the Study of Innovation and Learning Technologies 2015: Learning in the Technological Era. Raanana: The Open University of Israel. 
ers to "master academic content regardless of time, place, or pace of learning" (U.S. Department of Education, 2013). Such programs include "online and traditional courses, dual enrollment and early high schools, project based and community based learning, and credit recovery (i.e. Diploma Plus)" (U.S. Department of Education, 2013). Moreover, this strategy employs various teaching methodologies, while providing learners with the credits for the learning opportunities gained via lifelong experiences or other means by demonstrating adequate skill levels (i.e. competence) (Hyman, 2012). Learners can access preferred learning methodology that provides them with academic experience to develop and enhance specific skills needed to support their working careers. For example, the ability to make good decisions when faced with complex situations, the ability to research information in order to identify a solution, the ability to set goals and work towards achieving these goals, as well as the ability to communicate well are all skills needed in a number of organizations. Subsequently, learners can assume positions with little training on the job, and greater confidence (Gravill, Compeau, \& Marcolin, 2006). CBL strategy can deliver greater flexibility, efficiency, and lower costs to learners, while at the same time, cultivating greater employability. The aim of CBL is to create various paths to college education, while taking advantage of innovative information system technologies not as part of traditional in-class education but rather as an online skills enhancement tool by itself. Such tools are not reserved only for adults. For example, Generation $\mathrm{Z}$ have been using popular CBL to develop their own Science, Technology, Engineering, and Math (STEM) skills including Websites such as Khan Academy (www.khanacademy.org), Reading Plus (www.readingplus.com), or the Stanford's Educational Program for Gifted Youth (EPGY) (epgy.stanford.edu) to name a few. Moreover, over the past several years there has been a growing use of free and open tools such as YouTube, iTunes U, online courses, Web 2.0, Massively Open Online Courses (MOOCs), digital books, and digital notes. While a significant number of research studies has been done on the benefits of computer simulations as a skill development tool, the majority of such studies have focused on using the tools as part of face-to-face courses or to augment traditional learning modalities. However, there is a very limited number of research studies that have been conducted on the measurements of skill enhancements in fully online courses and programs, as opposed to measuring the benefits of such computer simulations as well as competency-based projects to augment in-class courses (Levy, 2005). Additionally, there are still limited empirical results on the use of computer simulations and competency-based projects being used as part of fully online learning courses. Thus, in this paper we have developed a quasi-experimental research using such instrument on pre- and post-tests to collect the set of 12 management skills from learners attending fully-online courses, including competency-based computer simulations and those that didn't. Therefore, the main research question guiding our study was:

RQ: What is the effect of computer simulations and competency-based projects on management skills enhancement in online learning courses?

\section{Literature Review}

\section{E-Learning and Life-Long Learning}

The significant growth of e-learning systems has been well documented in literature as over the past two decades (Geri, 2012; Levy, Ramim, \& Hackney, 2013). While e-learning systems have been extensively used for academic content delivery, they have been also adopted and integrated into business use, especially when it comes to corporate training and ensuring knowledge continuity in the organization (Koohang \& Paliszkiewicz, 2013). As the $21^{\text {st }}$ century is characterized as the 'knowledge economy', one of the most significant organizational assets is the knowledge of employees (Koohang, Paliszkiewicz, Nord, \& Ramim, 2014). As such, the demand to corporate and organizational knowledge delivery increases, while e-learning has been in the forefront of 
life-long learning tools available for employees when it comes to human resources (HR) training, professional certifications, annual credit attainment, and alike (Gafni \& Geri, 2010).

Nowadays, e-learning plays a significant role in an employee's knowledge acquisition and an efficient way for organizations to ensure their workforce is up to par with the latest developments that pertains to their work. Accordingly, one of the major roles of e-learning when it comes to knowledge acquisition is the assisting in skill enhancement, that can immediately be translated to better employee efficiency (Levy, 2005). Moreover, over the years employees are promoted to become managers in various organizations, while having very limited management skills (Rubin \& Dierdorff, 2009). Acquiring management skills is not an easy task; however, it appears that elearning content delivery can provide an efficient and cost effective way of doing so. Moreover, literature suggests that computer simulations do have positive impact on employee skills (Noy, 2014; Noy, Raban, \& Ravid, 2006). However, there appear to be very limited research related to the role of online simulations and more specifically, the use of competency-based simulations in e-learner's management skills enhancements. As such, this study attempts to fill the gap by trying to assess the benefits of competency-based simulations that are delivered via e-learning systems. More precisely, it attempts to see if these competency-based simulations delivered to e-learners during their academic courses exert significant enhancement to their management skills.

\section{Skills and Competencies}

Skills have been the cornerstone of all mankind development (Brown, Green, \& Lauder, 2001). According to Rasmussen (1983), skills are critical for human functioning as a foundational block for good performance in any task provided. Brown et al. (2001) emphasized the centrality of skills for human development by indicating that "it is widely argued that global economy competitiveness rest on the knowledge and skills of the workforce" (p. 1). Additionally, Brown et al. (2001) outlined the Human Capital Theory and its role in the economy prosperity of nations. They indicated that over the past 230 years human capital has been treated homogenously with more or less the same rate of productivity. Moreover, the need to increase organizational productivity has been tied directly to the increase of volume of machinery and employees that operate such machines. However, Brown et al. (2001) criticized such approaches by indicating that as globalization increases and the shift to knowledge economy is in full-force, there must also be a re-focusing of the theories to account the significant differences between employee skills as the single most important factor contributing to organizational productivity and ultimately success. Therefore, over the past several decades, companies are demanding incoming employees to be competent on the job, especially the educated workforce coming with academic degrees (Piccoli, Ahmad, \& Ives, 2001). As such, hiring managers expect that academic programs will prepare their graduates with the right skills set that can be applied upon hiring (Lee \& Mirchandani, 2010; Torkzadeh \& Lee, 2003). For example, in the medical and health professions, a significant part of academic courses is devoted to skill enhancements (Berendonk, Stalmeijer, \& Schuwirth, 2013). Moreover, the emphasis in medical programs is to develop, as well as enhance, the "skills and qualities doctors need to have to care for patients" (Morcke, Dornan, \& Eika, 2012, p. 856). According to Boyatzis and Kolb (1991), a skill refers to a "combination of ability, knowledge and experience that enables a person to do something well" (p. 280). Thus, when medical and health professionals (i.e., surgeons, physicians, nurses, therapists, etc.) graduate from their academic degree program, they are required to demonstrate the skills that they have learned during their academic experience. That high-level of demonstrated skills (i.e., competency) is expected for certification and licenses (Bronsburg, 2011; Morcke et al., 2012). Beaudoin, Kurtz, and Eden (2009) introduced a definition based on prior literature that claimed competencies to be "a specialized system of abilities, proficiencies, or dispositions to learn or do something successfully, or to reach a specific goal, prerequisites for meaningful activities and which are influenced through experience and learning" (p. 277). This competency achievement philosophy is consistent with 
the models of the U.S. Department of Labor (2015), that developed subject specific competency models.

In some academic fields, such as medicine and engineering, the focus is almost exclusively on academic knowledge transfer for the purpose of skills development (i.e., "what we need students to demonstrate they know"). In other academic fields such as management, including information systems, a significant number of academic institutions appear to focus on academic knowledge transfer, for the purpose of content delivery and learning outcomes (i.e., "what we want students to know"), and less on skill development that is so crucial for employability (Compeau \& Higgins, 1995; Kayworth \& Leidner, 2000). Having said that, computer simulations and competency-based projects have a significant role in helping learners hone such skills. In general, while their use is not widespread as in other fields, computer simulations and competency-based projects have demonstrated great value in management education (Keys \& Wolfe, 1990; Noy, 2014; Noy et al., 2006). Furthermore, research studies have demonstrated that computer simulations and competency-based projects can indeed assist in providing students with achieving fundamental skills that are needed upon graduation (Keh et al., 2008; Koh et al., 2010). In order to demonstrate the linkage between skills and competencies, Figure 1 highlights the relationship between the two (i.e., skill level \& competency level), while providing a theoretical framework for this study.

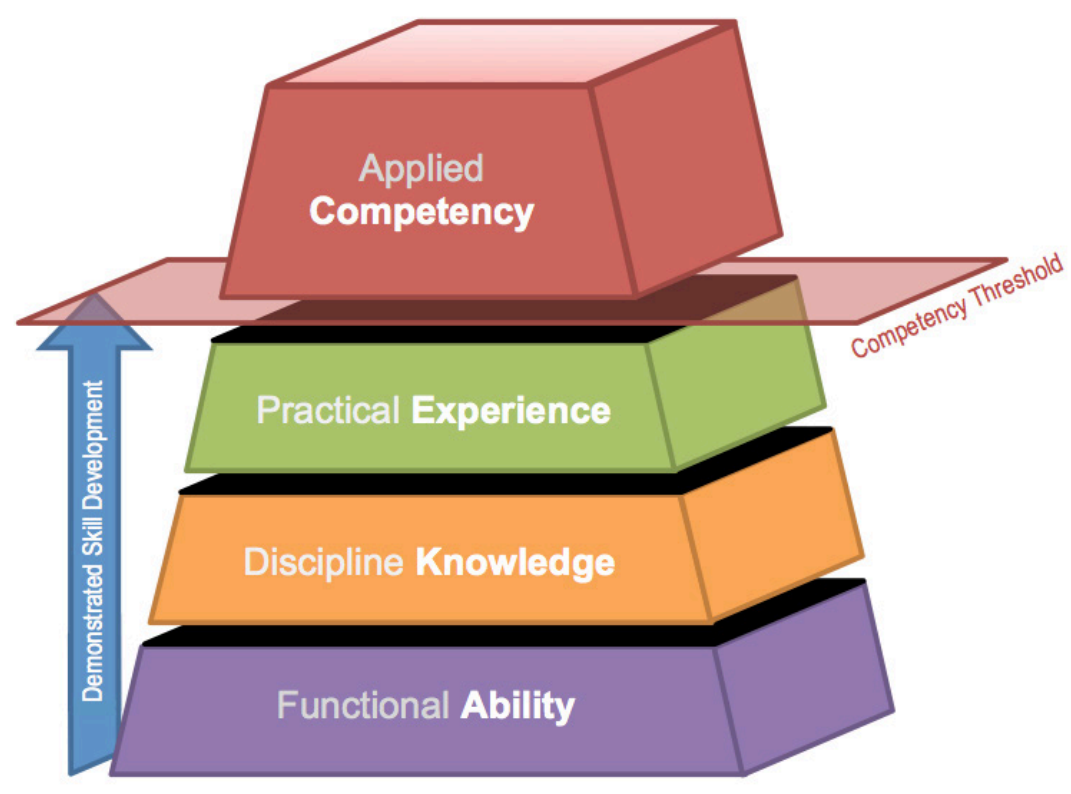

Figure 1. The Competency Pyramid: Relationship Between Skill Development and Competency Level

\section{Methodology}

\section{Instrument}

Self-reported instruments to measure skills have been criticized over the years for their internal validity (Carlton \& Levy, 2015). However, some scholars indicate that there is still validity in using such measures when it comes to complex multivariate procedural-type skills (Gravill et al., 2006; Jacobs \& Roodenburg, 2014). Thus, this quantitative study used a survey-based instrument to collect the skills from participants using a self-reported approach. This study built on the instrument used by the seminal work of Boyatzis and Kolb (1991, 1995), who developed a selfreported instrument to measure 12 management skills that pertain to businesses and are expected 
from a student graduating from management programs. Specifically, the core use of their measures was to compare the enhancements of skills over an academic experience, be it a course or a full program, where students are engaged in skill enhancements activities. Such skills are critical for those graduating from academic institutions, as these individuals are the future workforces including future managers. Given that management skills are challenging to measure, scholars in the field agree that self-reported skill level assessments are acceptable and indeed one of the ways to know what an individual feels about their own competence level when it comes to procedural-type skills (Gravill et al., 2006). As such, we have developed a study to collect the set of 12 management skills using a 36-item instrument (three items per skill) from online courses that included computer simulations compared with a control group of those that didn't experience the simulations, but were in other sections of the same management courses. The instrument scale ranged from 1='no skill or ability' to 7= 'I'm an expert in doing this'.

\section{Experimental Design and Simulations}

This study was designed as a quasi-experiment, given the fact the control over the assignment of participants was by the university's registration system (Levy \& Ellis, 2011). The control group included one course in Project Management in the undergraduate level and one course in Management Information Systems at the graduate Masters of Business Administration (MBA), distributed about equally. The experimental group included two courses in Project Management in the undergraduate level and two courses in Management Information Systems at the graduate MBA, distributed about equally. The same professor taught all courses fully-online, however, given adjustment in accreditation and/or course objective requirements, computer simulations were introduced. The control group included the content covered in a regular e-learning fashion: weekly discussion board assignments, quizzes on chapter readings, current event papers, as well as a final exam. The experimental groups included online simulation via WileyPLUS (https://www.wileyplus.com/) of an SAP ${ }^{\circledR}$ Enterprise Resource Planning (ERP) project for the graduate MBA students and the use of Microsoft Project ${ }^{\mathrm{TM}} 2010$ for the undergraduate students. Graduate students were asked to conduct several ERP modules within WileyPLUS to understand business processes, while undergraduate students were ask to use Microsoft Project ${ }^{\mathrm{TM}}$ to develop a project documentation report with Work-Based Structure (WBS), budget planning, resource allocation, as well as the project's Gant chart.

\section{Data Collection}

We developed a Web-based instrument to assess the 12 management skills using the 36 survey items along with some demographics information to ensure the groups were relatively similar. The instrument was fully anonymous and informed participants that there is no right or wrong answer, while they should do their best to provide a self estimation of their actual skill level that corresponds to their combined ability, knowledge, and experience for each of the given item asked. A definition of skill was provided to the participants at the top of the survey. Each group of students was asked to take the survey at the start of the term, and then asked to take it again at the end of the 16-week term (The Fall and Winter terms where 16 weeks long, but the Summer term was 14 weeks long). Data was collected during the 2012-2013 academic year (summer included).

\section{Results}

A total of 253 surveys have been collected over the four groups (pre-test control group, pre-test experimental group, post-test control group, \& post-test experimental group). Table 1 provides the gender distribution of the learners who participated in all four groups. We have attempted to ensure that those who have taken the pre-test also will complete the post-test, however, given the 
nature of the quasi-experiment and real-life settings, a few students either dropped or elected not to further participate in the post-test survey, which explains the drop in the post-test sample size.

Table 1: Gender Distribution of the Learners

\begin{tabular}{|c|c|c|c|c|c|}
\hline \multirow[b]{2}{*}{ Test } & \multirow[b]{2}{*}{ Gender } & \multicolumn{2}{|c|}{ Control Group } & \multicolumn{2}{|c|}{ Experimental Group } \\
\hline & & Frequency & Percentage (\%) & Frequency & Percentage (\%) \\
\hline 芯 & Female & 21 & $42.0 \%$ & 37 & $44.0 \%$ \\
\hline 常 & Male & 29 & $58.0 \%$ & 47 & $56.0 \%$ \\
\hline & & 50 & & 84 & \\
\hline 范 & Female & 21 & $42.9 \%$ & 31 & $44.3 \%$ \\
\hline$\stackrel{8}{2}$ & Male & 28 & $57.1 \%$ & 39 & $55.7 \%$ \\
\hline
\end{tabular}

As part of the data analysis, we have verified the reliability of the 12 management skills using Cronbach's Alpha (Cronbach, 1951). Alpha levels of 0.7 and above have been reported to indicate strong reliability for the constructs (Boudreau, Gefen, \& Straub, 2001; Straub, 1989). Table 2 provides the outcome of this analysis, which suggests that all 12 skills demonstrated very high reliability ranging from Cronbach's Alpha of 0.835 to 0.955 .

Table 2: Cronbach's Alpha Reliability Analysis for the 12 Management Skills Measures

\begin{tabular}{lcc} 
Management Skills & No. of Items & $\begin{array}{c}\text { Cronbach's } \\
\text { Alpha }\end{array}$ \\
\hline Help Skills (HLS) & 3 & 0.835 \\
Adapting Skills (ADS) & 3 & 0.898 \\
Planning Skills (PLS) & 3 & 0.870 \\
Information Gathering Skills (IGS) & 3 & 0.853 \\
Information Analysis Skills (IAS) & 3 & 0.899 \\
Quantitative Skills (QNS) & 3 & 0.916 \\
Technology Skills (TCS) & 3 & 0.952 \\
Goal-Setting Skills (GSS) & 3 & 0.955 \\
Action Skills (ACS) & 3 & 0.886 \\
Initiative Skills (INS) & 3 & 0.919 \\
Leadership Skills (LSS) & 3 & 0.952 \\
Relationship Skills (RES) & 3 & 0.920 \\
\hline
\end{tabular}

Prior to investigating the skill increase, an Analysis of Variance (ANOVA) for the 12 management skills was conducted to check if the pre-test of both groups is similar (Terrell, 2012). Our findings indicate that 10 out of the 12 skills were not significantly different on the pre-tests between the experimental and control groups ( $p$ ranged from 0.167 to 0.836 ), aside from the LSS and RES, which were slightly lower $\mathrm{p}$-values $\left(p_{L S S}=0.018 \& p_{R E S}=0.053\right)$ for the pre-test of the control group compared to the pre-test of the experimental group. Figure 2 provides the star-graph view for the 12 management skills on the pre- and post-test for the control group. 


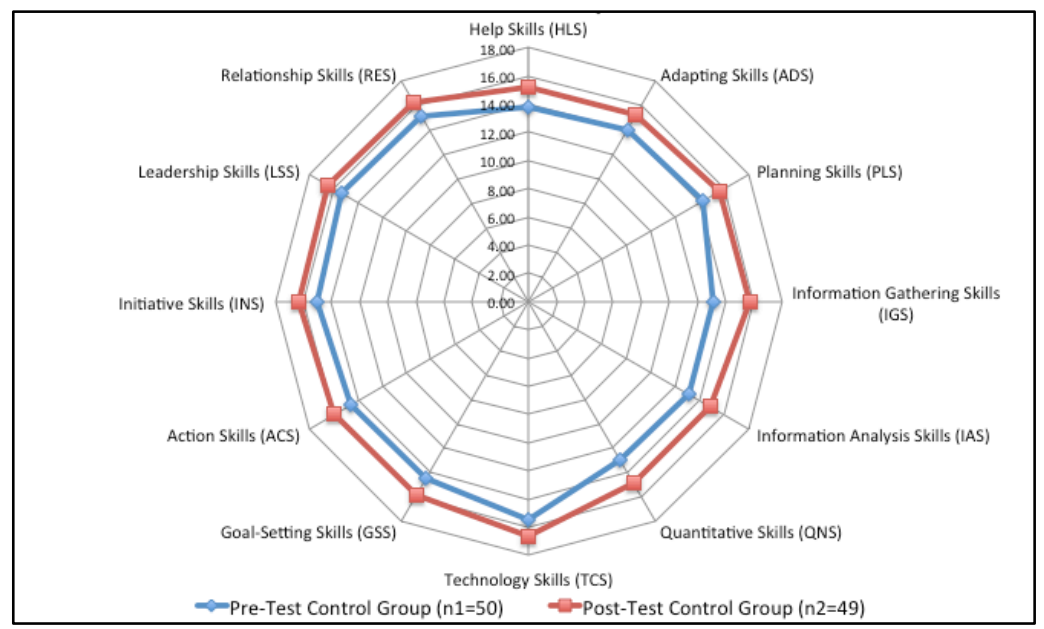

Figure 2. The 12 Management Skills for Pre- and Post-Tests Control Group $\left(\mathrm{n}_{1}=50, \mathrm{n}_{2}=49\right)$

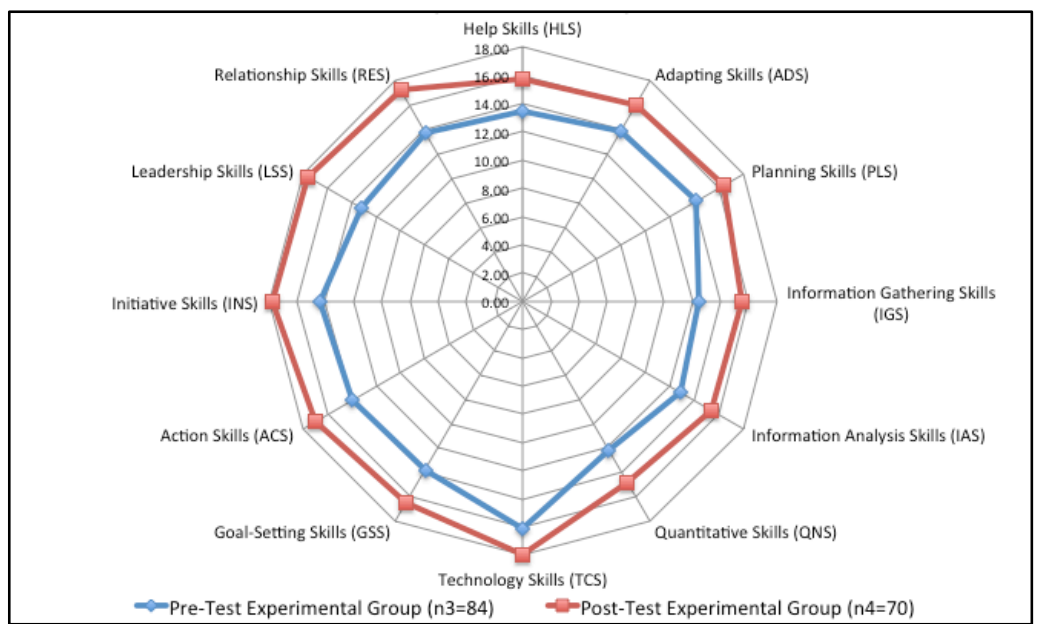

Figure 3. The 12 Management Skills for Pre- and Post-Tests Experimental Group $\left(\mathrm{n}_{3}=84, \mathrm{n}_{4}=70\right)$

In addressing the main RQ, we have conducted a t-test on the mean increases of the overall total management skills enhancement differences between the experimental group enhancements $\left(\Delta_{E G}\right)$ and control group enhancements $\left(\Delta_{C G}\right)$. The results indicate that although the overall management skills mean total for the pre-test control group was slightly higher than the mean total for the pretest of the experimental group (171.52 vs. 164.29), the experimental group demonstrated a significant $(p<0.001)$ enhancement of the total management skills in the post-test compared to the control group (189.05 vs. 197.85). Figure 3 provides the star-graph view for the 12 management skills on the pre- and post-tests for the experimental group (See Table 3). Figure 4 provides the star-graph view for the mean increases (i.e. $\Delta_{\text {skill }}$ ) in the 12 management skills for the experimental and control groups. 


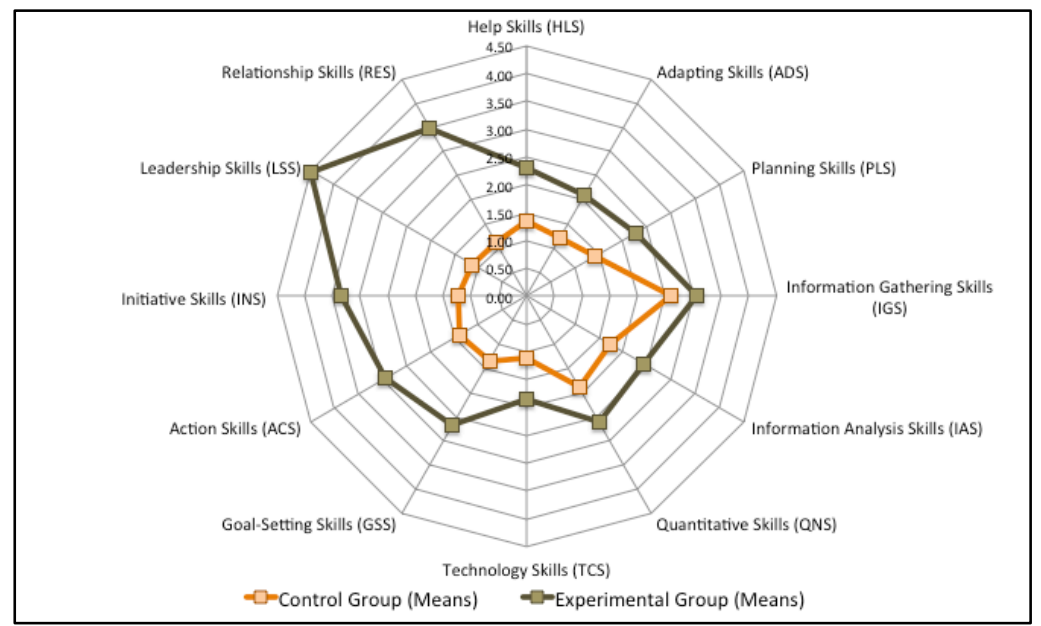

Figure 4. The 12 Management Skills Mean Enhancements for Control vs. Experimental Groups

Table 3 provides an overview of the whole study results including the means and standard deviations (SD) scores for the pre-test of the control and experimental groups, the post-test of the control and experimental groups, the mean increases (i.e. $\Delta_{\text {skill }}$ ) of the two groups, along with the ANOVA results for the mean increases and significance levels of the 12 skills based on the aggregated scores, as well as the t-test of the overall total management skills enhancement differences between the two groups.

Table 3: ANOVA Results for the 12 Management Skills Enhancement Differences for Control vs. Experimental Groups and t-test of Overall Total Management Skills Enhancement Differences

\begin{tabular}{|c|c|c|c|c|c|c|c|c|c|c|c|c|c|}
\hline \multirow{3}{*}{ Management Skills } & \multirow{2}{*}{\multicolumn{2}{|c|}{\begin{tabular}{|c|} 
Pre-Test \\
Control Group \\
(n1=50)
\end{tabular}}} & \multirow{2}{*}{\multicolumn{2}{|c|}{$\begin{array}{c}\text { Pre-Test } \\
\text { Experimental } \\
\text { Group }(\mathrm{n} \mathbf{2}=\mathbf{8 4})\end{array}$}} & \multirow{2}{*}{\multicolumn{2}{|c|}{$\begin{array}{c}\text { Post-Test } \\
\text { Control Group } \\
\text { (n3=49) }\end{array}$}} & \multirow{2}{*}{\multicolumn{2}{|c|}{\begin{tabular}{|c|} 
Post-Test \\
Experimental \\
Group $(\mathrm{n} 4=70)$
\end{tabular}}} & \multirow{3}{*}{\begin{tabular}{|c|} 
Skills \\
Enhancement \\
$\begin{array}{c}\text { Control Group } \\
\text { (Means) }\end{array}$ \\
\end{tabular}} & \multirow{3}{*}{\begin{tabular}{|c|} 
Skills \\
Enhancement \\
Experimental \\
Group \\
\end{tabular}} & \multicolumn{3}{|c|}{ ANOVA } \\
\hline & & & & & & & & & & & \multirow[t]{2}{*}{$\mathbf{F}$} & \multirow{2}{*}{\multicolumn{2}{|c|}{ Sig. }} \\
\hline & Means & SD & Means & SD & Means & SD & Means & SD & & & & & \\
\hline Help Skills (HLS) & 13.82 & 3.28 & 13.47 & 3.90 & 15.16 & 2.51 & 15.77 & 3.70 & 1.34 & 2.30 & 8.91 & 0.041 & $*$ \\
\hline Adapting Skills (ADS) & 14.02 & 3.64 & 13.90 & 3.45 & 15.25 & 3.10 & 16.00 & 3.37 & 1.23 & 2.10 & 4.26 & 0.108 & \\
\hline Planning Skills (PLS) & 14.30 & 3.90 & 14.20 & 3.43 & 15.72 & 2.96 & 16.46 & 2.76 & 1.42 & 2.26 & 13.65 & 0.021 & * \\
\hline Information Gathering Skills (IGS) & 13.10 & 3.73 & 12.47 & 3.48 & 15.70 & 3.33 & 15.54 & 3.50 & 2.60 & 3.07 & 2.47 & 0.191 & \\
\hline Information Analysis Skills (IAS) & 13.12 & 4.07 & 12.94 & 3.18 & 14.86 & 3.29 & 15.38 & 3.43 & 1.74 & 2.45 & 1.04 & 0.366 & \\
\hline Quantitative Skills (QNS) & 12.96 & 4.44 & 12.16 & 3.62 & 14.84 & 3.36 & 14.77 & 3.42 & 1.88 & 2.61 & 4.41 & 0.104 & \\
\hline Technology Skills (TCS) & 15.50 & 4.08 & 16.08 & 4.41 & 16.61 & 3.90 & 17.92 & 3.43 & 1.11 & 1.84 & 6.11 & 0.069 & \\
\hline Goal-Setting Skills (GSS) & 14.50 & 3.73 & 13.78 & 3.83 & 15.84 & 3.40 & 16.46 & 3.50 & 1.34 & 2.69 & 19.28 & 0.012 & $*$ \\
\hline Action Skills (ACS) & 14.56 & 3.84 & 13.98 & 3.76 & 15.96 & 2.97 & 16.92 & 2.69 & 1.40 & 2.94 & 11.04 & 0.027 & * \\
\hline Initiative Skills (INS) & 15.06 & 3.91 & 14.35 & 3.67 & 16.28 & 3.32 & 17.69 & 2.56 & 1.22 & 3.35 & 59.42 & 0.002 & ** \\
\hline Leadership Skills (LSS) & 15.38 & 4.40 & 13.14 & 4.79 & 16.51 & 3.28 & 17.62 & 2.93 & 1.13 & 4.47 & 302.45 & 0.000 & **** \\
\hline \multirow[t]{2}{*}{ Relationship Skills (RES) } & 15.20 & 3.70 & 13.82 & 3.30 & 16.32 & 3.01 & 17.31 & 2.93 & 1.12 & 3.49 & 30.45 & 0.005 & $* *$ \\
\hline & & & & & & & & & & & $\mathrm{t}$ & \multicolumn{2}{|c|}{ Sig. (2-tailed) } \\
\hline Total Management Skills --> & 171.52 & & 164.29 & & 189.05 & & 197.85 & & 17.53 & 33.56 & 10.52 & 0.000 & $* * *$ \\
\hline
\end{tabular}

\section{Discussions}

While it is evident from the results that all 12 management skills were enhanced via the courses that incorporated computer simulation and competency-based projects, the amount of increase vary slightly among the skills set, which is consistent with prior literature (Keh et al., 2008; Koh et al., 2010). For example, it was observed that the most significant for the degree of increases were (in order of p-values) on leadership skills (LSS), initiative skills (INS), relationship skills (RES), goal-setting skills (GSS), planning sills (PLS), actions skills (ACS), and help skills (HLS). Marginal degree of significance for the increase was observed for technology skills (TCS), while non-significance for the degree of increases were observed for quantitative skills (QNS), adaptive skills (ADS), Information gathering skills (IGS), and information analysis skills (IAS). The most interesting finding that we encountered was that while technology skills, information gathering 
skills, and information analysis skills were originally anticipated to have the most significant increases, the simulation and competency project used might not have placed emphasis on these skills. This is somewhat paradoxical given that the treatment was the use of online computer simulations. It is speculated that given the type of participants and generation $\mathrm{Z}$ participants, the data indicated otherwise. Additional research is needed to uncover these specific issues, including investigation of the specific sub-types of such skills. For example, technology skills may need to be focused more on specific technologies or areas such as Information Technology (IT) skills, Cybersecurity skills, research and analysis skills, and so on.

\section{Study Limitations}

This quasi-experiment exhibits several limitations. The first limitation of this study includes the fact that the data collection was conducted at only two institutions. Moreover, the second limitation of this study includes the use of a single professor and narrow type of courses (Project Management \& MIS); although the focus of the work was on the simulation, use of additional diverse professors may provide different results.

\section{Recommendation for Future Research}

Additional experimentations are needed to uncover the benefits of computer simulations and competency-based projects in skill enhancements within academic courses. Moreover, future work can explore further skills beyond those measured here, where it can also be focused on the specific academic program and profession category under study. Moreover, future work may further study why learners felt that the simulations helped skill development using qualitative investigation techniques. Also, there is a potential to introduce new simulations and competency-based projects, to address those specific skills that were observed to have smaller degree of skill enhancements, something that may also require additional investigation as well. Also, there is merit to understanding the interactions between learners-to-learners and learners-to-instructor in building skills towards the highest competency levels.

\section{Conclusions}

This research investigated the role of computer simulations and competency-based projects on a set of 12 management skills during online courses. This study included a $2 \times 2$ quasi-experimental design with a control group and an experimental group (not randomly assigned), that comprised of both a pre-test and a post-test assessment of the 12 management skills. Overall, six courses three undergraduate and three MBA courses - were included. A comparison between the two pretest groups (experimental vs. control) showed no significant differences on 10 of the 12 skills, which indicates that the base-comparison is adequate, given that we had no say on the allocation of participants into the groups. Our experimental comparison indicated that, while both groups experienced significant increases in a majority of the skills, the experimental group that included computer simulations and competency-based projects demonstrated an overall significant $(p<0.001)$ enhancement in the 12 management skills combined, whereas, individually, seven skills demonstrated a significant mean increases, where the rest demonstrated not significant, yet still positive increases by the experimental group over the control group. Such results indicate that overall, there is a credible value for the use of computer simulations and competency-based projects as an important component of e-learning content delivery when the focus is to increase skills in general, and managerial skills in particular. 


\section{Acknowledgments}

We would like to thank the editor-in-chief Dr. Gila Kurtz, Dr. Janice Whatley, and Dr. Nitza Geri, as well as the anonymous referees, for their careful review and valuable suggestions. Additionally, we wish to acknowledge the input of participants at the Chais 2015 conference on Learning Technologies Research, February 2015, where an earlier version of part of this article was presented.

\section{References}

Beaudoin, M. F., Kurtz, G., \& Eden, S. (2009). Experiences and opinions of e-learners: What works, what are the challenges, and what competencies ensure successful online learning. Interdisciplinary Journal of E-Learning and Learning Objects, 5, 275-289. Retrieved from http://www.ijello.org/Volume5/IJELLOv5p275-289Beaudoin665.pdf

Berendonk, C., Stalmeijer, R. E., \& Schuwirth, L. W. (2013). Expertise in performance assessment: Assessors' perspectives. Advances in Health Sciences Education, 18(4), 559-571. doi: 10.1007/s10459012-9392-x

Boudreau, M.-C., Gefen, D., \& Straub, D. W. (2001). Validation in information systems research: A stateof-the-art assessment. MIS Quarterly, 25(1), 1-17.

Boyatzis, R. E., \& Kolb, D. A. (1991). Assessing individuality in learning: The learning skills profile. Educational Psychology, 11(3), 279-295.

Boyatzis, R. E., \& Kolb, D. A. (1995). From learning styles to learning skills: The executive skills profile. Journal of Managerial Psychology \& Marketing, 10(5), 3-17.

Bronsburg, S. E. (2011). The impact of an osteopathic medical program on information technology skills of physicians entering the healthcare workforce (Doctoral dissertaion). Nova Southeastern University, Ft. Lauderdale, Florida.

Brown, P., Green, A., \& Lauder, H. (2001). High skills: Globalization, competitiveness, and skill formation: Globalization, competitiveness, and skill formation: Oxford University Press.

Carlton, M., \& Levy, Y. (2015). Expert assessment of the top platform independent cybersecurity skills for non-it professionals. Proceedings of the 2015 IEEE SoutheastCon, Ft. Lauderdale, Florida, pp. 1-6.

Compeau, D. R., \& Higgins, C. A. (1995). Application of social cognitive theory to training for computer skills. Information Systems Research, 6(2), 118-143. doi: 10.1287/isre.6.2.118

Cronbach, L. J. (1951). Coefficient alpha and the internal structure of tests. Psychometrik, 16(3), 297-334.

Gafni, R., \& Geri, N. (2010). Time management: Procrastination tendency in individual and collaborative tasks. Interdisciplinary Journal of Information, Knowledge, and Management, 5, 115-125. Retrieved from http://www.ijikm.org/Volume5/IJIKMv5p115-125Gafni448.pdf

Geri, N. (2012). The resonance factor: Probing the impact of video on student retention in distance learning. Interdisciplinary Journal of E-Learning and Learning Objects, 8, 1-13. Retrieved from http://www.ijello.org/Volume8/IJELLOv8p001-013Geri0794.pdf

Gravill, J. I., Compeau, D. R., \& Marcolin, B. L. (2006). Experience effects on the accuracy of selfassessed user competence. Information \& Management, 43, 378-394.

Hyman, P. (2012). In the year of disruptive education. Communications of the ACM, 55(12), 20-22.

Jacobs, K. E., \& Roodenburg, J. (2014). The development and validation of the self-report measure of cognitive abilities: A multitrait-multimethod study. Intelligence, 42, 5-21.

Kayworth, T. R., \& Leidner, D. E. (2000). The global virtual manager: A prescription for success. European Management Journal, 18(2), 183. 
Keh, H. C., Wang, K. M., Wai, S. S., Huang, J. Y., Hui, L., \& Wu., J. J. (2008). Distance-learning for advanced military education: Using wargame simulation course as an example. International Journal of Distance Education Technologies, 6(4), 50-61.

Keys, B., \& Wolfe, J. (1990). The role of management games and simulations in education and research. Journal of Management, 16(2), 307-336.

Koh, C., Tan, H. S., Tan, K. C., Fang, L., Fong, F., Kan, D., ...Wee, M. L. (2010). Investigating the effect of $3 \mathrm{~d}$ simulation-based learning on the motivation and performance of engineering students. Journal of Engineering Education, 99(3), 237-251. doi: 10.1002/j.2168-9830.2010.tb01059.x

Koohang, A., \& Paliszkiewicz, J. (2013). Knowledge construction in e-learning: An empirical validation of an active learning model. Journal of Computer Information Systems, 53(3), 109-114.

Koohang, A., Paliszkiewicz, J., Nord, J. H., \& Ramim, M. (2014). Advancing a theoretical model for knowledge construction in e-learning. Online Journal of Applied Knowledge Management, 2(2), 12-25.

Lee, K., \& Mirchandani, D. (2010). Dynamics of the importance of IS/IT skills. Journal of Computer Information Systems, 50(4), 67-79.

Levy, Y. (2005). A case study of management skills comparison in online and on-campus mba programs. International Journal of Information and Communication Technology Education, 1(3), 1-20.

Levy, Y., \& Ellis, T. J. (2011). A guide for novice researchers on experimental and quasi-experimental studies in information systems research. Interdisciplinary Journal of Information, Knowledge, and Management, 6, 151-161. Retrieved from http://www.ijikm.org/Volume6/IJIKMv6p151161Levy553.pdf

Levy, Y., Ramim, M. M., \& Hackney, R. A. (2013). Assessing ethical severity of e-learning systems security attacks. Journal of Computer Information Systems, 53(3), 75-84.

Morcke, A. M., Dornan, T., \& Eika, B. (2012). Outcome (competency) based education: An exploration of its origins, theoretical basis, and empirical evidence. Advances in Health Sciences Education, 18(4), 851-863. doi: 10.1007/s10459-012-9405-9

Noy, A. (2014). A computer-assisted auction simulation. Simulation \& Gaming, 45(3), 371-393.

Noy, A., Raban, D. R., \& Ravid, G. (2006). Testing social theories in computer-mediated communication through gaming and simulation. Simulation \& Gaming, 37(2), 174-194.

Piccoli, G., Ahmad, R., \& Ives, B. (2001). Web-based virtual learning environment a research framework and preliminary assessment of effectiveness in basic it skills training. MIS Quarterly, 25(4), 401-426.

Rasmussen, J. (1983). Skills, rules, and knowledge; signals, signs, and symbols, and other distinctions in human performance models. Systems, Man and Cybernetics, IEEE Transactions on(3), 257-266.

Rubin, R. S., \& Dierdorff, E. C. (2009). How relevant is the MBA? Assessing the alignment of required curricula and required managerial competencies. Academy of Management Learning \& Education, $8(2), 208-224$.

Straub, D. W. (1989). Validating instruments in MIS research. MIS Quarterly, 13(2), 147-170.

Terrell, S. R. (2012). Statistics translated: A step-by-step guide to analyzing and interpreting data. New York, NY: The Guilford Press.

Torkzadeh, G., \& Lee, J. (2003). Measures of perceived end-user computing skills. Information \& Management, 40(7), 607-615.

U.S. Department of Education. (2013). Competency-based learning or personalized learning. Retrieved from http://www.ed.gov/oii-news/competency-based-learning-or-personalized-learning

U.S. Department of Labor. (2015). Competency model. Retrieved February 9, 2015, 2015, from http://www.careeronestop.org/CompetencyModel/ 


\section{Biographies}

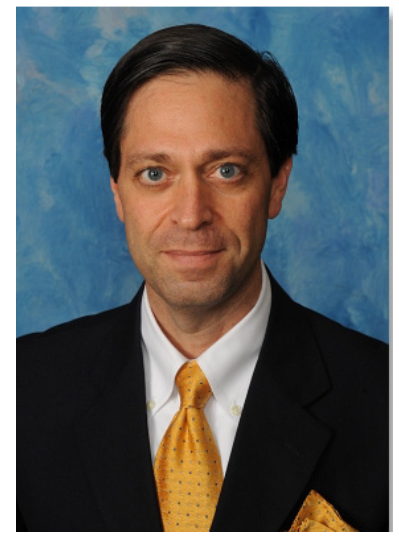

Dr. Yair Levy is a Professor of Information Systems and Cybersecurity at the College of Engineering and Computing at Nova Southeastern University. He serves as the director of the Center for eLearning Security Research (http://CeLSR.nova.edu/). During the mid to late 1990s, he helped NASA develop e-learning platforms and manage Web infrastructures. He earned his Bachelor's degree in Aerospace Engineering from the Technion, Israel Institute of Technology. He received his MBA with MIS concentration and Ph.D. in MIS from Florida International University. His current research interests include cybersecurity, user-authentication, information privacy, skills, and e-learning system security. He leads the LevyCyLab research group. Dr. Levy is the author of Assessing the Value of e-Learning Systems (2006) and over 60 peer-reviewed publications. His research publications appear in the Journal of Organizational and End User Computing (JOEUC), Journal of Cases on Information Technology (JCIT), International Journal of Information Systems in the Service Sector (IJISSS), Journal of Information Systems Education (JISE), Informing Science Journal (ISJ), Campus-Wide Information Systems (CWIS), The Internet and Higher Education (IHE), journal of Computers \& Education, the International Journal of Information and Communications Technology Education (IJICTE), Journal of Internet Banking and Commerce (JIBC), Interdisciplinary Journal of E-Learning and Learning Objects (IJELLO), International Journal of Doctoral Studies (IJDS), as well as in peer-reviewed conference proceedings. Additionally, he published invited book chapters and encyclopedias. His research publications have been cited by over 1,350 peer-reviewed manuscripts. To find out more about him, please visit his Website: http://cec.nova.edu/ levyy/

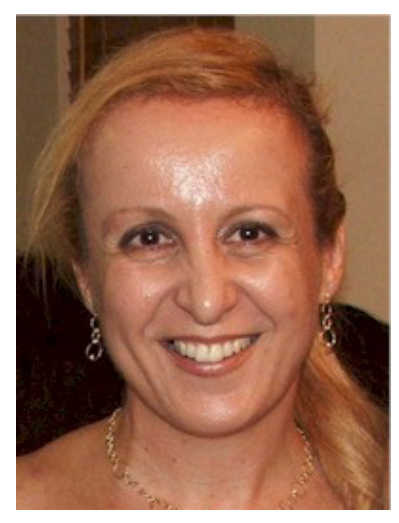

Dr. Michelle Ramim is an Associate Professor of Information Technology (IT) at the Department of Computer Information Technology in the Fisher School of Technology, at Hodges University, Naples, Florida. She has extensive experience in IT consulting. Dr. Ramim directed the development and implementations of several IT projects including promotional and interactive websites for major enterprises such as Debeer (Diamond Trading Company). Her current research interests include ethical issues with IT, information security and crisis management, legal aspects of computing, as well as ethical decision making. She has published articles in peer-reviewed outlets including journals, conference proceedings, encyclopedias, and an invited chapter. Moreover, she has been serving as a referee research reviewer for national and international scientific journals, conference proceedings, as well as MIS textbooks. She earned her Bachelor's degree from Barry University in Miami Florida. Dr. Ramim has received her Executive MBA from Florida International University. She completed her Ph.D. in Information Systems at the Graduate School of Computer and Information Sciences, Nova Southeastern University in the area of ethical decision making. 